\title{
Age-related Changes in Bone Weights and Their Components in Rats
}

\author{
Haruzo IIDA and Satoshi FUKUDA \\ Division of Comparative Radiotoxicology, National Institute of Radiological Sciences, 4-9-1 \\ Anagawa, Inage-ku, Chiba-shi, Chiba 263, Japan
}

(Received 20 October 1992/Accepted 29 January 1993)

\begin{abstract}
Age-related changes in the wet, dry and ash weights and components such as water, organic substance, ash, calcium and phosphorus of femur, tibia and first lumbar vertebra and serum biochemical constituents related to bone metabolism were examined in Wistar rats. A total of 60 males and 60 females were used, and every five rats of both sexes were examined at 1 and 2 months of age and then at intervals of 3 months between 3 and 30 months of age. Each bone weight increased rapidly up to 3 months of age and then gradually up to 12 months of age in females and 9 months of age in males, but thereafter decreased at 27 and 30 months of age in males. Between 1 and 6 or 9 months of age in both sexes, a decrease in water content, increases in ash, calcium and phosphorus, and almost no change in organic substance in each bone were observed. After 15 months of age in males, an increase in water content, decreases in ash content, calcium and phosphorus, and almost no changes in organic substance were observed in males. The value of serum calcium decreased up to 12 months of age but then increased after 18months of age in both sexes. Serum phosphorus and alkalinephosphatase activity decreased up to 9 months of age in both sexes. The data obtained in this study supported the results in our previous study that the peak bone strength of the femur and peak bone volume of trabecular bone of the proximal metaphysis of the tibia were at 12 months of age in both sexes in Wistar rats. -KEY WORDS : age-related change, bone components, bone weight, calcium, rat
\end{abstract}

\section{ラットの加歯に伴う骨重量および含有成分量の変化}

\author{
飯田治三・福田 俊
}

放射線医学総合研究所内部被ばく研究部

ラットは骨に関する基礎研究や疾患の研究にも多く 用いられているが, ラットの骨は個体が成熟に達した 以降も骨端に成長軟骨帯が永く残る[3]ために長さ が,また太さも增加し続け，さらに組織学的な動態も 成長期に観察されるモデリング様式を示し続ける[1] 点で成人の骨とは異なることが指摘されている。

著者らはラットの加秢に伴う骨の変化を骨強度試験 法や骨梁骨の組織形態計測法によって，ラットにも人 [4]と同様な骨量のピークが存在することを認め, こ の共通点はラットを骨に関する実験に使用する年粭を 決めたり，実験結果を考察する上で重要な指標になる
ことを報告した $[2]$ 。

しかしラットの骨重量, 特に含有成分量の加秢に伴 う変化に関する詳細な報告は少なく $[6-9], し か も そ$ れらの結果には相違がみられる。また骨梁骨と皮質骨 では代謝や薬物などに対する反応に相違があることが 報告されている $[5]$ 。したがって，骨の重量や含有成 分量についても加粭に伴う変化を明確にし，また骨強 度や骨梁骨と形態計測の結果と比較することは, ラッ トと人の骨に関する種差を検討するだけでなく，薬物 や種々の実験処置に対する影響を評価する上でも重要 である。 
そこで本研究では, ラットの骨の重量, 含有成分量 および骨代謝に関連した血清成分の年齢変化について 検討した。

\section{材料および方法}

動物は，本研究所動物生産施設で生産された Wis$\operatorname{tar}$-Mishima (WM) ラットの雄60匹，雌60匹，計120 匹を用いた。飼育室の条件は, 温度 $22 \pm 2^{\circ} \mathrm{C}$, 相対湿 度 $55 \pm 5 \%$, 照明 12 時間明暗サイクル (AM 8：00点 燈，PM 8：00消燈）とした。飼料は市販のマウス・ラ ット用固型飼料 $(\mathrm{MB}-1$, 株式会社船橋農場, カル シウム含有量： $1.10 \%$, リン含有量 : $1.40 \%$ ）を, 飲 水は給水瓶を用いて市水をそれぞれ自由椇取させた。 飼育ケージはラット飼育用ステンレス製金網床ケージ (縦 $34 \mathrm{~cm}$, 横 $46 \mathrm{~cm}$, 高さ $23 \mathrm{~cm}, ト キ ワ$ 科学器機株 式会社）を用いた。

骨の観察は生後 $1 ， 2 ， 3 ， 6 ， 9 ， 12 ， 15 ， 18$, $21 ， 24 ， 27$ および 30 力月龄の計 12 時点で行った。各時 点で雄 5 匹, 雌 5 匹を供し, クロロホルム麻酔下で腹 大静脈から採血した後, 右側の大腿骨, 脛骨および第 1 腰椎を採取した。

骨重量および各含有成分量の測定は，以下のような 方法で行った。まず，採取した骨の筋肉や㖪を完全に 取り除いた後，その骨（以下生骨と略す）の重量を測 定した。次に, 乾燥器で $100^{\circ} \mathrm{C}, 24$ 時間乾燥し（以下 乾燥骨と略す)，その重量を測定した。さらに乾燥骨 を電気炉で $600^{\circ} \mathrm{C} ， 24$ 時間灰化し（以下灰化骨と略 す)，重量を測定した。

灰化骨は硝酸で完全に溶解後，適正な測定濃度にす るために，イオン交換水で希釈してカルシウムおよび リン值の測定を行った。カルシウム值は Ortho-cresolphthalein complexone 発色法 (Calcium C-test, 和光純薬株式会社), リン值は Molybdenum blue 法 (Phosphar B-test，和光純薬株式会社）を用いて測定 した。
得られた各重量の値から，以下のようにして各含有 成分量を計算した。

水分含有量 $(\%)=\frac{\text { 生骨重量一乾燥骨重量 }}{\text { 生骨重量 }} \times 100$ 有機成分含有量 $(\%)=\frac{\text { 乾燥骨重量 }- \text { 灰化骨重量 }}{\text { 生骨重量 }} \times 100$ 灰分含有量 $(\%)=\frac{\text { 灰化骨重量 }}{\text { 生骨重量 }} \times 100$ カルシウム含有量 $(\%)=\frac{\text { カルシウム量 }}{\text { 生骨重量 }} \times 100$

リン含有量 $(\%)=\frac{\text { リン量 }}{\text { 生骨重量 }} \times 100$

血液は，3,000rpm，15分間遠心し，血清を分離し た。血清総カルシウム值およびリン值は，骨の場合と 同じ方法で測定した。アルカリフォスファターゼ活性 值は Bessey-Lowry 法（オートバック ALP・opt ベー リンガー・マンハイム) を用いて測定した。

\section{成}

\section{1. 体重 (Table 1.)}

雄の体重は 9 力月秢まで增加したが，27力月秢以降 減少した。雌は12力月柃まで増加し，さらに18力月粼 以降も増加がみられた。

2. 骨重量 (Table 2.)

（1）大腿骨 雄の生骨，乾燥骨および兏化骨重量 はいずれも 9 力月粭まで増加した後変化しなかった。 しかし生骨および乾燥骨重量は30力月鮯，灰化骨重量 は27および30力月龄で低い值を示した。雌では生骨重 量は 6 力月䤅, 乾燥骨重量は 9 力月柃，灰化骨重量は 12 月月秢まで増加した後変化しなかった。

（2）脛骨 雄の生骨，乾燥骨および兏化骨重量は いずれも 9 力月龄まで増加した後変化しなかった。し かし生骨および乾燥骨重量は27力月龄，灰化骨重量は

Table 1. Age-related changes in the body weight of both sexes

\begin{tabular}{|c|c|c|c|c|c|c|c|c|c|c|c|c|}
\hline \multirow{2}{*}{ Sex } & \multicolumn{12}{|c|}{ Age in months } \\
\hline & 1 & 2 & 3 & 6 & 9 & 12 & 15 & 18 & 21 & 24 & 27 & 30 \\
\hline Male & 50 & 236 & 298 & 379 & 412 & 430 & 430 & 447 & 448 & 431 & 402 & 408 \\
\hline (g) & \pm 3 & \pm 7 & \pm 17 & \pm 13 & \pm 13 & \pm 18 & \pm 13 & \pm 42 & \pm 14 & \pm 47 & $\pm 25^{\circ}$ & \pm 12 \\
\hline Female & 50 & 139 & 186 & 234 & 250 & 292 & 291 & 317 & 321 & 318 & 337 & 326 \\
\hline (g) & \pm 3 & \pm 11 & \pm 17 & \pm 8 & \pm 14 & \pm 14 & \pm 22 & \pm 27 & \pm 14 & \pm 25 & \pm 21 & \pm 25 \\
\hline
\end{tabular}

Each value indicates the mean \pm S.D. for 5 rats. 
Table 2. Wet, dry and ash weights of femur, tibia and first lumbar vertebra

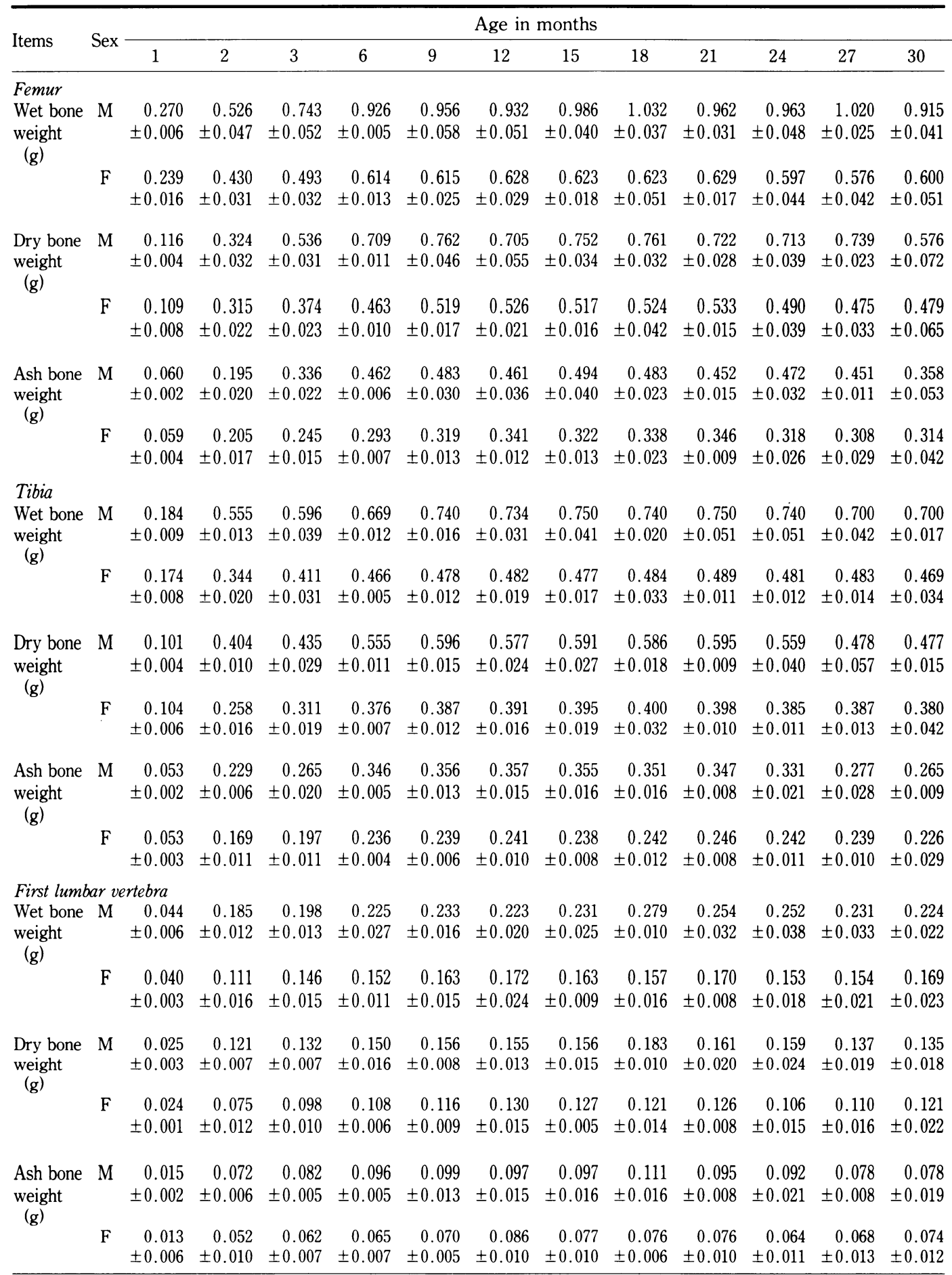

Each value indicates the mean \pm S.D. for 5 rats. 
Table 3. Water, organic substance and ash contents relative to wet weight of femur, tibia and first lumbar vertebra

\begin{tabular}{|c|c|c|c|c|c|c|c|c|c|c|c|c|c|}
\hline \multirow{2}{*}{ Items } & \multirow{2}{*}{ Sex } & \multicolumn{12}{|c|}{ Age in months } \\
\hline & & 1 & 2 & 3 & 6 & 9 & 12 & 15 & 18 & 21 & 24 & 27 & 30 \\
\hline \multirow{3}{*}{$\begin{array}{c}\text { Femur } \\
\text { Water } \\
\text { content } \\
(\%)\end{array}$} & & & & & & & & & & & & & \\
\hline & M & $\begin{array}{r}57.8 \\
\pm 0.9\end{array}$ & $\begin{array}{r}32.4 \\
\pm 1.2\end{array}$ & $\begin{array}{r}27.8 \\
\pm 1.2\end{array}$ & $\begin{array}{r}23.4 \\
\pm 1.2\end{array}$ & $\begin{array}{r}20.2 \\
\pm 0.7\end{array}$ & $\begin{array}{r}23.4 \\
\pm 0.6\end{array}$ & $\begin{array}{r}23.7 \\
\pm 0.8\end{array}$ & $\begin{array}{r}26.2 \\
\pm 1.7\end{array}$ & $\begin{array}{r}25.0 \\
\pm 2.6\end{array}$ & $\begin{array}{r}26.0 \\
\pm 1.9\end{array}$ & $\begin{array}{r}27.6 \\
\pm 2.5\end{array}$ & $\begin{array}{r}37.2 \\
\pm 5.7\end{array}$ \\
\hline & $\mathrm{F}$ & $\begin{array}{r}54.4 \\
\pm 0.8\end{array}$ & $\begin{array}{r}26.6 \\
\pm 0.4\end{array}$ & $\begin{array}{r}24.2 \\
\pm 0.9\end{array}$ & $\begin{array}{r}24.5 \\
\pm 0.6\end{array}$ & $\begin{array}{r}15.7 \\
\pm 1.3\end{array}$ & $\begin{array}{r}16.2 \\
\pm 0.8\end{array}$ & $\begin{array}{r}17.0 \\
\pm 0.3\end{array}$ & $\begin{array}{r}15.9 \\
\pm 2.0\end{array}$ & $\begin{array}{r}15.3 \\
\pm 0.8\end{array}$ & $\begin{array}{r}15.4 \\
\pm 1.0\end{array}$ & $\begin{array}{r}17.6 \\
\pm 0.6\end{array}$ & $\begin{array}{r}20.5 \\
\pm 5.0\end{array}$ \\
\hline \multirow{2}{*}{$\begin{array}{l}\text { Organic } \\
\text { substance } \\
\text { content } \\
(\%)\end{array}$} & M & $\begin{array}{r}20.1 \\
\pm 0.9\end{array}$ & $\begin{array}{r}24.9 \\
\pm 0.9\end{array}$ & $\begin{array}{r}26.9 \\
\pm 0.9\end{array}$ & $\begin{array}{r}27.0 \\
\pm 1.5\end{array}$ & $\begin{array}{r}29.2 \\
\pm 1.0\end{array}$ & $\begin{array}{r}28.7 \\
\pm 0.7\end{array}$ & $\begin{array}{r}26.2 \\
\pm 2.1\end{array}$ & $\begin{array}{r}27.0 \\
\pm 0.8\end{array}$ & $\begin{array}{r}28.1 \\
\pm 1.1\end{array}$ & $\begin{array}{r}25.1 \\
\pm 0.6\end{array}$ & $\begin{array}{r}28.2 \\
\pm 2.5\end{array}$ & $\begin{array}{r}23.8 \\
\pm 1.8\end{array}$ \\
\hline & $\mathrm{F}$ & $\begin{array}{r}20.7 \\
\pm 0.8\end{array}$ & $\begin{array}{r}25.7 \\
\pm 1.1\end{array}$ & $\begin{array}{r}26.1 \\
\pm 0.6\end{array}$ & $\begin{array}{r}27.7 \\
\pm 0.8\end{array}$ & $\begin{array}{r}32.4 \\
\pm 0.9\end{array}$ & $\begin{array}{r}29.5 \\
\pm 0.3\end{array}$ & $\begin{array}{r}31.4 \\
\pm 1.2\end{array}$ & $\begin{array}{r}29.8 \\
\pm 1.1\end{array}$ & $\begin{array}{r}29.9 \\
\pm 1.2\end{array}$ & $\begin{array}{r}29.7 \\
\pm 0.8\end{array}$ & $\begin{array}{r}29.0 \\
\pm 1.6\end{array}$ & $\begin{array}{r}27.3 \\
\pm 2.3\end{array}$ \\
\hline \multirow{2}{*}{$\begin{array}{l}\text { Ash } \\
\text { content } \\
(\%)\end{array}$} & M & $\begin{array}{r}22.1 \\
\pm 0.4\end{array}$ & $\begin{array}{r}45.3 \\
\pm 0.6\end{array}$ & $\begin{array}{r}45.3 \\
\pm 0.6\end{array}$ & $\begin{array}{r}46.6 \\
\pm 1.1\end{array}$ & $\begin{array}{r}50.6 \\
\pm 0.7\end{array}$ & $\begin{array}{r}47.9 \\
\pm 0.8\end{array}$ & $\begin{array}{r}50.1 \\
\pm 2.4\end{array}$ & $\begin{array}{r}46.8 \\
\pm 1.3\end{array}$ & $\begin{array}{r}47.0 \\
\pm 1.5\end{array}$ & $\begin{array}{r}49.0 \\
\pm 1.8\end{array}$ & $\begin{array}{r}44.2 \\
\pm 0.3\end{array}$ & $\begin{array}{r}39.0 \\
\pm 4.5\end{array}$ \\
\hline & $\mathrm{F}$ & $\begin{array}{r}24.9 \\
\pm 0.3\end{array}$ & $\begin{array}{r}47.7 \\
\pm 1.3\end{array}$ & $\begin{array}{r}49.7 \\
\pm 0.5\end{array}$ & $\begin{array}{r}47.8 \\
\pm 0.4\end{array}$ & $\begin{array}{r}51.8 \\
\pm 0.8\end{array}$ & $\begin{array}{r}54.3 \\
\pm 1.0\end{array}$ & $\begin{array}{r}51.7 \\
\pm 1.2\end{array}$ & $\begin{array}{r}54.2 \\
\pm 1.4\end{array}$ & $\begin{array}{r}54.8 \\
\pm 0.5\end{array}$ & $\begin{array}{r}54.9 \\
\pm 1.4\end{array}$ & $\begin{array}{r}53.4 \\
\pm 1.6\end{array}$ & $\begin{array}{r}52.2 \\
\pm 3.3\end{array}$ \\
\hline \multirow[t]{2}{*}{$\begin{array}{l}\text { Tibia } \\
\text { Water } \\
\text { content } \\
(\%)\end{array}$} & M & $\begin{array}{r}45.3 \\
\pm 1.0\end{array}$ & $\begin{array}{r}26.5 \\
\pm 0.7\end{array}$ & $\begin{array}{r}27.0 \\
\pm 1.1\end{array}$ & $\begin{array}{r}21.3 \\
\pm 1.1\end{array}$ & $\begin{array}{r}20.3 \\
\pm 0.8\end{array}$ & $\begin{array}{r}21.4 \\
\pm 0.8\end{array}$ & $\begin{array}{r}21.1 \\
\pm 0.9\end{array}$ & $\begin{array}{r}20.8 \\
\pm 0.9\end{array}$ & $\begin{array}{r}21.3 \\
\pm 0.7\end{array}$ & $\begin{array}{r}24.5 \\
\pm 1.7\end{array}$ & $\begin{array}{r}30.2 \\
\pm 2.4\end{array}$ & $\begin{array}{r}21.9 \\
\pm 0.8\end{array}$ \\
\hline & $\mathrm{F}$ & $\begin{array}{r}41.1 \\
\pm 1.5\end{array}$ & $\begin{array}{r}25.4 \\
\pm 0.7\end{array}$ & $\begin{array}{r}24.2 \\
\pm 1.9\end{array}$ & $\begin{array}{r}19.1 \\
\pm 0.6\end{array}$ & $\begin{array}{r}19.0 \\
\pm 0.8\end{array}$ & $\begin{array}{r}19.0 \\
\pm 0.8\end{array}$ & $\begin{array}{r}17.5 \\
\pm 1.0\end{array}$ & $\begin{array}{r}17.4 \\
\pm 1.8\end{array}$ & $\begin{array}{r}18.6 \\
\pm 0.6\end{array}$ & $\begin{array}{r}19.9 \\
\pm 1.2\end{array}$ & $\begin{array}{r}19.9 \\
\pm 0.6\end{array}$ & $\begin{array}{r}19.2 \\
+3.5\end{array}$ \\
\hline \multirow{2}{*}{$\begin{array}{l}\text { Organic } \\
\text { substance } \\
\text { content } \\
(\%)\end{array}$} & M & $\begin{array}{r}25.7 \\
\pm 0.8\end{array}$ & $\begin{array}{r}31.8 \\
\pm 1.8\end{array}$ & $\begin{array}{r}28.6 \\
\pm 0.6\end{array}$ & $\begin{array}{r}29.2 \\
\pm 1.6\end{array}$ & $\begin{array}{r}32.5 \\
\pm 1.5\end{array}$ & $\begin{array}{r}30.0 \\
\pm 0.9\end{array}$ & $\begin{array}{r}31.5 \\
\pm 0.4\end{array}$ & $\begin{array}{r}31.8 \\
\pm 1.0\end{array}$ & $\begin{array}{r}33.0 \\
\pm 0.3\end{array}$ & $\begin{array}{r}30.8 \\
\pm 0.9\end{array}$ & $\begin{array}{r}30.3 \\
\pm 2.9\end{array}$ & $\begin{array}{r}30.2 \\
\pm 1.0\end{array}$ \\
\hline & $\mathrm{F}$ & $\begin{array}{r}28.5 \\
\pm 1.5\end{array}$ & $\begin{array}{r}25.9 \\
\pm 0.7\end{array}$ & $\begin{array}{r}27.8 \\
\pm 1.9\end{array}$ & $\begin{array}{r}30.2 \\
\pm 0.6\end{array}$ & $\begin{array}{r}31.0 \\
\pm 0.8\end{array}$ & $\begin{array}{r}31.0 \\
\pm 0.8\end{array}$ & $\begin{array}{r}32.7 \\
\pm 1.0\end{array}$ & $\begin{array}{r}32.5 \\
\pm 1.8\end{array}$ & $\begin{array}{r}31.0 \\
\pm 0.6\end{array}$ & $\begin{array}{r}29.8 \\
\pm 1.2\end{array}$ & $\begin{array}{r}30.6 \\
\pm 0.6\end{array}$ & $\begin{array}{r}31.5 \\
\pm 1.0\end{array}$ \\
\hline \multirow[t]{2}{*}{$\begin{array}{l}\text { Ash } \\
\text { content } \\
(\%)\end{array}$} & M & $\begin{array}{r}29.0 \\
\pm 0.6\end{array}$ & $\begin{array}{r}41.7 \\
\pm 1.5\end{array}$ & $\begin{array}{r}44.4 \\
\pm 0.8\end{array}$ & $\begin{array}{r}49.5 \\
\pm 0.7\end{array}$ & $\begin{array}{r}48.1 \\
\pm 1.0\end{array}$ & $\begin{array}{r}48.6 \\
\pm 0.5\end{array}$ & $\begin{array}{r}47.4 \\
\pm 0.5\end{array}$ & $\begin{array}{r}47.4 \\
\pm 1.0\end{array}$ & $\begin{array}{r}46.3 \\
\pm 1.0\end{array}$ & $\begin{array}{r}44.7 \\
\pm 1.1\end{array}$ & $\begin{array}{r}39.5 \\
\pm 2.5\end{array}$ & $\begin{array}{r}37.9 \\
\pm 0.7\end{array}$ \\
\hline & $\mathrm{F}$ & $\begin{array}{r}30.3 \\
\pm 0.7\end{array}$ & $\begin{array}{r}49.2 \\
\pm 0.9\end{array}$ & $\begin{array}{r}47.9 \\
\pm 1.4\end{array}$ & $\begin{array}{r}49.0 \\
\pm 0.5\end{array}$ & $\begin{array}{r}50.0 \\
\pm 0.4\end{array}$ & $\begin{array}{r}50.1 \\
\pm 0.1\end{array}$ & $\begin{array}{r}49.9 \\
\pm 0.6\end{array}$ & $\begin{array}{r}49.9 \\
\pm 1.5\end{array}$ & $\begin{array}{r}50.4 \\
\pm 0.9\end{array}$ & $\begin{array}{r}50.3 \\
\pm 1.6\end{array}$ & $\begin{array}{r}49.5 \\
\pm 0.7\end{array}$ & $\begin{array}{r}48.1 \\
\pm 3.0\end{array}$ \\
\hline \multicolumn{14}{|c|}{ First lumbar vertebra } \\
\hline \multirow[t]{2}{*}{$\begin{array}{l}\text { Water } \\
\text { content } \\
(\%)\end{array}$} & M & $\begin{array}{r}43.1 \\
\pm 1.4\end{array}$ & $\begin{array}{r}34.2 \\
\pm 2.0\end{array}$ & $\begin{array}{r}33.2 \\
\pm 1.0\end{array}$ & $\begin{array}{r}33.1 \\
\pm 1.1\end{array}$ & $\begin{array}{r}32.8 \\
\pm 2.1\end{array}$ & $\begin{array}{r}30.3 \\
\pm 1.0\end{array}$ & $\begin{array}{r}32.3 \\
\pm 2.1\end{array}$ & $\begin{array}{r}34.2 \\
\pm 1.5\end{array}$ & $\begin{array}{r}36.1 \\
\pm 6.5\end{array}$ & $\begin{array}{r}37.0 \\
\pm 1.7\end{array}$ & $\begin{array}{r}40.7 \\
\pm 2.1\end{array}$ & $\begin{array}{r}39.6 \\
\pm 4.0\end{array}$ \\
\hline & $\mathrm{F}$ & $\begin{array}{r}40.5 \\
\pm 3.5\end{array}$ & $\begin{array}{r}32.8 \\
\pm 1.8\end{array}$ & $\begin{array}{r}31.0 \\
\pm 0.8\end{array}$ & $\begin{array}{r}29.1 \\
\pm 1.7\end{array}$ & $\begin{array}{r}26.7 \\
\pm 3.7\end{array}$ & $\begin{array}{r}24.4 \\
\pm 2.0\end{array}$ & $\begin{array}{r}22.4 \\
\pm 1.8\end{array}$ & $\begin{array}{r}24.1 \\
\pm 1.2\end{array}$ & $\begin{array}{r}25.8 \\
\pm 1.2\end{array}$ & $\begin{array}{r}27.7 \\
\pm 2.9\end{array}$ & $\begin{array}{r}28.3 \\
\pm 1.3\end{array}$ & $\begin{array}{r}28.7 \\
\pm 4.4\end{array}$ \\
\hline \multirow{2}{*}{$\begin{array}{l}\text { Organic } \\
\text { substance } \\
\text { content } \\
(\%)\end{array}$} & M & $\begin{array}{r}23.8 \\
\pm 1.8\end{array}$ & $\begin{array}{r}26.6 \\
\pm 1.3\end{array}$ & $\begin{array}{r}25.4 \\
\pm 0.3\end{array}$ & $\begin{array}{r}24.4 \\
\pm 1.2\end{array}$ & $\begin{array}{r}24.0 \\
\pm 4.0\end{array}$ & $\begin{array}{r}26.1 \\
\pm 0.7\end{array}$ & $\begin{array}{r}25.7 \\
\pm 0.8\end{array}$ & $\begin{array}{r}25.9 \\
\pm 0.9\end{array}$ & $\begin{array}{r}26.2 \\
\pm 2.8\end{array}$ & $\begin{array}{r}26.5 \\
\pm 0.6\end{array}$ & $\begin{array}{r}25.5 \\
\pm 0.8\end{array}$ & $\begin{array}{r}25.6 \\
+2.0\end{array}$ \\
\hline & $\mathrm{F}$ & $\begin{array}{r}27.7 \\
\pm 2.8\end{array}$ & $\begin{array}{r}23.4 \\
\pm 1.2\end{array}$ & $\begin{array}{r}25.4 \\
\pm 0.6\end{array}$ & $\begin{array}{r}27.9 \\
\pm 1.3\end{array}$ & $\begin{array}{r}29.0 \\
\pm 1.6\end{array}$ & $\begin{array}{r}27.6 \\
\pm 2.2\end{array}$ & $\begin{array}{r}30.6 \\
\pm 0.8\end{array}$ & $\begin{array}{r}28.4 \\
\pm 2.0\end{array}$ & $\begin{array}{r}29.3 \\
\pm 2.7\end{array}$ & $\begin{array}{r}28.5 \\
\pm 1.0\end{array}$ & $\begin{array}{r}27.7 \\
\pm 1.5\end{array}$ & $\begin{array}{r}27.6 \\
\pm 2.8\end{array}$ \\
\hline \multirow[t]{2}{*}{$\begin{array}{l}\text { Ash } \\
\text { content } \\
(\%)\end{array}$} & M & $\begin{array}{r}34.0 \\
\pm 2.3\end{array}$ & $\begin{array}{r}39.2 \\
\pm 1.3\end{array}$ & $\begin{array}{r}41.4 \\
\pm 0.6\end{array}$ & $\begin{array}{r}42.6 \\
\pm 0.9\end{array}$ & $\begin{array}{r}43.2 \\
\pm 2.8\end{array}$ & $\begin{array}{r}43.5 \\
\pm 1.3\end{array}$ & $\begin{array}{r}42.0 \\
\pm 1.4\end{array}$ & $\begin{array}{r}39.8 \\
\pm 1.0\end{array}$ & $\begin{array}{r}37.7 \\
\pm 4.0\end{array}$ & $\begin{array}{r}36.6 \\
\pm 1.2\end{array}$ & $\begin{array}{r}34.0 \\
\pm 1.5\end{array}$ & $\begin{array}{r}34.8 \\
\pm 2.1\end{array}$ \\
\hline & $\mathrm{F}$ & $\begin{array}{r}31.8 \\
+2.5\end{array}$ & $\begin{array}{r}43.8 \\
\pm 1.8\end{array}$ & $\begin{array}{r}43.8 \\
\pm 0.6\end{array}$ & $\begin{array}{r}42.9 \\
\pm 1.1\end{array}$ & $\begin{array}{r}44.3 \\
\pm 3.3\end{array}$ & $\begin{array}{r}48.0 \\
\pm 3.0\end{array}$ & $\begin{array}{r}47.0 \\
\pm 1.5\end{array}$ & $\begin{array}{r}47.5 \\
\pm 1.2\end{array}$ & $\begin{array}{r}44.9 \\
\pm 2.1\end{array}$ & $\begin{array}{r}43.7 \\
\pm 2.6\end{array}$ & $\begin{array}{r}44.0 \\
\pm 1.3\end{array}$ & $\begin{array}{r}43.7 \\
\pm 2.4\end{array}$ \\
\hline
\end{tabular}

Each value indicates the mean \pm S.D. for 5 rats. 
Table 4. Calcium and phosphorus contents relative to wet weights of femur, tibia and first lumbar vertebra

\begin{tabular}{|c|c|c|c|c|c|c|c|c|c|c|c|c|c|}
\hline \multirow{2}{*}{ Items } & \multirow{2}{*}{ Sex } & \multicolumn{12}{|c|}{ Age in months } \\
\hline & & 1 & 2 & 3 & 6 & 9 & 12 & 15 & 18 & 21 & 24 & 27 & 30 \\
\hline \multirow{3}{*}{$\begin{array}{l}\text { Femur } \\
\text { Calcium } \\
\text { content } \\
(\%)\end{array}$} & & & & & & & & & & & & & \\
\hline & M & $\begin{array}{r}6.6 \\
\pm 1.0\end{array}$ & $\begin{array}{r}15.3 \\
\pm 1.6\end{array}$ & $\begin{array}{r}16.5 \\
\pm 1.2\end{array}$ & $\begin{array}{r}20.0 \\
\pm 1.4\end{array}$ & $\begin{array}{r}21.0 \\
\pm 1.4\end{array}$ & $\begin{array}{r}20.4 \\
\pm 0.5\end{array}$ & $\begin{array}{r}26.0 \\
\pm 2.2\end{array}$ & $\begin{array}{r}23.7 \\
\pm 2.8\end{array}$ & $\begin{array}{r}22.4 \\
\pm 1.9\end{array}$ & $\begin{array}{r}22.8 \\
\pm 2.6\end{array}$ & $\begin{array}{r}22.1 \\
\pm 2.3\end{array}$ & $\begin{array}{r}19.6 \\
\pm 3.3\end{array}$ \\
\hline & $\mathrm{F}$ & $\begin{array}{r}8.9 \\
\pm 3.0\end{array}$ & $\begin{array}{r}19.3 \\
\pm 2.1\end{array}$ & $\begin{array}{r}19.3 \\
\pm 2.9\end{array}$ & $\begin{array}{r}21.3 \\
\pm 0.9\end{array}$ & $\begin{array}{r}23.4 \\
\pm 0.4\end{array}$ & $\begin{array}{r}24.1 \\
\pm 1.6\end{array}$ & $\begin{array}{r}22.3 \\
\pm 1.9\end{array}$ & $\begin{array}{r}24.1 \\
\pm 2.2\end{array}$ & $\begin{array}{r}25.0 \\
\pm 3.2\end{array}$ & $\begin{array}{r}24.9 \\
\pm 1.3\end{array}$ & $\begin{array}{r}21.3 \\
\pm 7.3\end{array}$ & $\begin{array}{r}24.3 \\
\pm 4.0\end{array}$ \\
\hline \multirow[t]{2}{*}{$\begin{array}{l}\text { Phosphorus } \\
\text { content } \\
(\%)\end{array}$} & M & $\begin{array}{r}5.7 \\
\pm 0.5\end{array}$ & $\begin{array}{r}7.3 \\
\pm 0.8\end{array}$ & $\begin{array}{r}7.3 \\
\pm 0.4\end{array}$ & $\begin{array}{r}9.0 \\
\pm 0.3\end{array}$ & $\begin{array}{r}8.6 \\
\pm 0.5\end{array}$ & $\begin{array}{r}8.8 \\
\pm 0.5\end{array}$ & $\begin{array}{r}9.3 \\
\pm 1.1\end{array}$ & $\begin{array}{r}9.1 \\
\pm 1.3\end{array}$ & $\begin{array}{r}7.7 \\
\pm 0.8\end{array}$ & $\begin{array}{r}8.5 \\
\pm 1.4\end{array}$ & $\begin{array}{r}10.6 \\
\pm 0.3\end{array}$ & $\begin{array}{r}9.5 \\
\pm 0.9\end{array}$ \\
\hline & $\mathrm{F}$ & $\begin{array}{r}6.4 \\
\pm 0.3\end{array}$ & $\begin{array}{r}6.9 \\
+1.7\end{array}$ & $\begin{array}{r}12.2 \\
\pm 0.4\end{array}$ & $\begin{array}{r}11.4 \\
\pm 0.9\end{array}$ & $\begin{array}{r}11.9 \\
\pm 0.2\end{array}$ & $\begin{array}{r}13.1 \\
\pm 0.2\end{array}$ & $\begin{array}{r}12.6 \\
\pm 0.4\end{array}$ & $\begin{array}{r}13.2 \\
\pm 0.3\end{array}$ & $\begin{array}{r}12.8 \\
\pm 1.4\end{array}$ & $\begin{array}{r}13.2 \\
\pm 0.7\end{array}$ & $\begin{array}{r}12.9 \\
\pm 1.0\end{array}$ & $\begin{array}{r}12.4 \\
\pm 0.8\end{array}$ \\
\hline \multirow{3}{*}{$\begin{array}{l}\text { Tibia } \\
\text { Calcium } \\
\text { content } \\
(\%)\end{array}$} & & & & & & & & & & & & & \\
\hline & M & $\begin{array}{r}12.4 \\
\pm 0.8\end{array}$ & $\begin{array}{r}16.8 \\
\pm 1.1\end{array}$ & $\begin{array}{r}18.3 \\
\pm 0.6\end{array}$ & $\begin{array}{r}21.3 \\
\pm 0.7\end{array}$ & $\begin{array}{r}21.4 \\
\pm 0.7\end{array}$ & $\begin{array}{r}21.3 \\
\pm 0.9\end{array}$ & $\begin{array}{r}21.5 \\
\pm 0.5\end{array}$ & $\begin{array}{r}18.1 \\
\pm 0.5\end{array}$ & $\begin{array}{r}19.2 \\
\pm 3.5\end{array}$ & $\begin{array}{r}16.7 \\
\pm 0.7\end{array}$ & $\begin{array}{r}15.9 \\
\pm 1.2\end{array}$ & $\begin{array}{r}15.1 \\
\pm 0.4\end{array}$ \\
\hline & $\mathrm{F}$ & $\begin{array}{r}11.5 \\
\pm 0.5\end{array}$ & $\begin{array}{r}17.6 \\
\pm 0.8\end{array}$ & $\begin{array}{r}17.1 \\
\pm 1.0\end{array}$ & $\begin{array}{r}20.7 \\
\pm 1.4\end{array}$ & $\begin{array}{r}21.2 \\
\pm 2.0\end{array}$ & $\begin{array}{r}20.4 \\
\pm 1.1\end{array}$ & $\begin{array}{r}20.1 \\
\pm 1.6\end{array}$ & $\begin{array}{r}21.1 \\
\pm 1.0\end{array}$ & $\begin{array}{r}21.1 \\
\pm 0.3\end{array}$ & $\begin{array}{r}20.8 \\
\pm 1.0\end{array}$ & $\begin{array}{r}20.7 \\
\pm 1.1\end{array}$ & $\begin{array}{r}20.1 \\
\pm 1.9\end{array}$ \\
\hline \multirow[t]{2}{*}{$\begin{array}{l}\text { Phosphorus } \\
\text { content } \\
(\%)\end{array}$} & M & $\begin{array}{r}5.6 \\
\pm 0.2\end{array}$ & $\begin{array}{r}8.7 \\
\pm 0.7\end{array}$ & $\begin{array}{r}8.8 \\
\pm 0.4\end{array}$ & $\begin{array}{r}9.8 \\
\pm 0.4\end{array}$ & $\begin{array}{r}9.4 \\
\pm 1.1\end{array}$ & $\begin{array}{r}9.3 \\
\pm 0.5\end{array}$ & $\begin{array}{r}9.7 \\
\pm 0.5\end{array}$ & $\begin{array}{r}9.4 \\
\pm 0.9\end{array}$ & $\begin{array}{r}9.2 \\
\pm 1.4\end{array}$ & $\begin{array}{r}8.7 \\
\pm 0.8\end{array}$ & $\begin{array}{r}8.6 \\
\pm 0.5\end{array}$ & $\begin{array}{r}8.0 \\
\pm 0.3\end{array}$ \\
\hline & $\mathrm{F}$ & $\begin{array}{r}5.7 \\
\pm 0.3\end{array}$ & $\begin{array}{r}9.1 \\
\pm 0.1\end{array}$ & $\begin{array}{r}8.4 \\
+0.7\end{array}$ & $\begin{array}{r}9.2 \\
\pm 0.6\end{array}$ & $\begin{array}{r}8.8 \\
\pm 0.9\end{array}$ & $\begin{array}{r}8.7 \\
+0.7\end{array}$ & $\begin{array}{r}9.0 \\
\pm 0.4\end{array}$ & $\begin{array}{r}8.8 \\
\pm 0.2\end{array}$ & $\begin{array}{r}9.3 \\
\pm 0.5\end{array}$ & $\begin{array}{r}9.4 \\
\pm 0.3\end{array}$ & $\begin{array}{r}9.5 \\
\pm 0.6\end{array}$ & $\begin{array}{r}9.4 \\
\pm 0.6\end{array}$ \\
\hline \multicolumn{14}{|c|}{ First lumbar vertebra } \\
\hline \multirow[t]{2}{*}{$\begin{array}{l}\text { Calcium } \\
\text { content } \\
(\%)\end{array}$} & $\mathrm{M}$ & $\begin{array}{r}15.1 \\
\pm 1.4\end{array}$ & $\begin{array}{r}14.4 \\
\pm 2.0\end{array}$ & $\begin{array}{r}16.9 \\
\pm 1.0\end{array}$ & $\begin{array}{r}15.8 \\
\pm 1.1\end{array}$ & $\begin{array}{r}18.0 \\
\pm 2.1\end{array}$ & $\begin{array}{r}16.5 \\
\pm 1.0\end{array}$ & $\begin{array}{r}17.2 \\
\pm 2.1\end{array}$ & $\begin{array}{r}14.5 \\
\pm 1.5\end{array}$ & $\begin{array}{r}13.6 \\
\pm 6.5\end{array}$ & $\begin{array}{r}14.5 \\
\pm 1.7\end{array}$ & $\begin{array}{r}12.4 \\
\pm 2.1\end{array}$ & $\begin{array}{r}13.2 \\
\pm 4.0\end{array}$ \\
\hline & $\mathrm{F}$ & $\begin{array}{r}15.2 \\
\pm 2.4\end{array}$ & $\begin{array}{r}15.4 \\
\pm 0.6\end{array}$ & $\begin{array}{r}13.9 \\
\pm 0.3\end{array}$ & $\begin{array}{r}15.5 \\
\pm 1.4\end{array}$ & $\begin{array}{r}16.0 \\
\pm 1.4\end{array}$ & $\begin{array}{r}17.5 \\
\pm 1.6\end{array}$ & $\begin{array}{r}17.8 \\
\pm 1.0\end{array}$ & $\begin{array}{r}18.4 \\
\pm 1.3\end{array}$ & $\begin{array}{r}18.4 \\
\pm 0.9\end{array}$ & $\begin{array}{r}17.2 \\
\pm 1.1\end{array}$ & $\begin{array}{r}16.9 \\
\pm 0.6\end{array}$ & $\begin{array}{r}17.0 \\
\pm 1.4\end{array}$ \\
\hline \multirow[t]{2}{*}{$\begin{array}{l}\text { Phosphorus } \\
\text { content } \\
(\%)\end{array}$} & M & $\begin{array}{r}6.1 \\
\pm 0.6\end{array}$ & $\begin{array}{r}7.4 \\
\pm 0.5\end{array}$ & $\begin{array}{r}8.6 \\
\pm 0.7\end{array}$ & $\begin{array}{r}8.2 \\
\pm 0.4\end{array}$ & $\begin{array}{r}8.7 \\
\pm 1.2\end{array}$ & $\begin{array}{r}8.2 \\
\pm 0.3\end{array}$ & $\begin{array}{r}8.5 \\
\pm 0.6\end{array}$ & $\begin{array}{r}7.4 \\
\pm 0.5\end{array}$ & $\begin{array}{r}6.8 \\
\pm 0.7\end{array}$ & $\begin{array}{r}7.2 \\
\pm 0.9\end{array}$ & $\begin{array}{r}6.1 \\
\pm 0.6\end{array}$ & $\begin{array}{r}6.5 \\
\pm 0.9\end{array}$ \\
\hline & $\mathrm{F}$ & $\begin{array}{r}5.9 \\
\pm 0.2\end{array}$ & $\begin{array}{r}8.4 \\
\pm 0.2\end{array}$ & $\begin{array}{r}7.2 \\
\pm 0.3\end{array}$ & $\begin{array}{r}7.4 \\
\pm 0.6\end{array}$ & $\begin{array}{r}7.3 \\
\pm 0.5\end{array}$ & $\begin{array}{r}8.5 \\
\pm 0.3\end{array}$ & $\begin{array}{r}9.0 \\
\pm 0.2\end{array}$ & $\begin{array}{r}9.7 \\
\pm 1.1\end{array}$ & $\begin{array}{r}8.8 \\
+0.8\end{array}$ & $\begin{array}{r}8.6 \\
\pm 0.9\end{array}$ & $\begin{array}{r}8.2 \\
\pm 0.3\end{array}$ & $\begin{array}{r}7.7 \\
\pm 0.9\end{array}$ \\
\hline
\end{tabular}

Each value indicates the mean \pm S.D. for 5 rats.

24 力月秢以降減少した。雌の各重量はいずれも 12 力月

䤅まで増加した後変化しなかった。

（3）第 1 腰椎 雄では各重量とも 6 力月龄まで増 加した後変化しなかった。しかし灰化骨重量は27カ月 齢以降減少した。雌では生骨重量は 9 カ月橉, 乾燥骨 および灰化骨重量は 12 力月㱓まで増加した後変化しな かった。

3. 各骨の含有水分, 有機成分および灰分量 (Table 3.)

（1）大腿骨 雄の水分含有量は 6 力月柃まで減少 した後変化しなかったが, 24 力月龄以降增加した。有 機成分含有量は 6 力月齢まで增加した後变化しなかっ た。灰分含有量は 9 力月秢まで増加した後変化しなか
つたが, 27 カ月龄以降減少した。雌では水分含有量は 9 力月龄まで減少, 有機成分含有量は 9 力月柃まで增 加, 灰分含有量は 12 力月觝まで増加した後変化しなか った。

（2）脛骨 雄の水分含有量は 6 力月龄まで減少し た後変化しなかったが, 24 力月龄以降增加した。有機 成分含有量は 2 月柃以降变化しなかった。灰分含有 量は 6 力月秢まで増加した後变化しなかったが, 15 力 月齢以降減少した。雌では水分含有量は 6 力月龄まで 減少した後変化しなかった。有機成分含有量は $1 \sim 3$ 力月齢でやや低值を示したが，以降変化しなかった。 灰分含有量は 6 力月齡まで増加した後変化しなかった。 
Table 5. Serum biochemical constituents

\begin{tabular}{|c|c|c|c|c|c|c|c|c|c|c|c|c|c|}
\hline \multirow{2}{*}{ Items } & \multirow{2}{*}{ Sex } & \multicolumn{12}{|c|}{ Age in months } \\
\hline & & 1 & 2 & 3 & 6 & 9 & 12 & 15 & 18 & 21 & 24 & 27 & 30 \\
\hline \multirow{4}{*}{$\begin{array}{l}\text { Calcium } \\
\text { concentration } \\
(\mathrm{mg} / \mathrm{d} \ell)\end{array}$} & M & 11.2 & 10.3 & 10.0 & 9.9 & 9.8 & 9.5 & 9.8 & 10.3 & 10.3 & 10.2 & 10.8 & 10.8 \\
\hline & & \pm 0.4 & \pm 0.5 & \pm 0.8 & \pm 0.5 & \pm 0.5 & \pm 0.3 & \pm 0.7 & \pm 0.6 & \pm 0.4 & \pm 0.4 & \pm 0.5 & \pm 0.8 \\
\hline & $\mathrm{F}$ & 11.3 & 10.3 & 10.2 & 10.3 & 10.1 & 9.9 & 9.9 & 10.8 & 10.7 & 10.6 & 10.7 & 11.0 \\
\hline & & \pm 0.5 & \pm 0.8 & \pm 0.8 & \pm 0.4 & \pm 0.6 & \pm 0.3 & \pm 0.6 & \pm 0.1 & \pm 0.4 & \pm 0.7 & \pm 0.7 & \pm 0.7 \\
\hline \multirow{4}{*}{$\begin{array}{l}\text { Phosphorus } \\
\text { concentration } \\
(\mathrm{mg} / \mathrm{d} \ell)\end{array}$} & M & 10.0 & 8.5 & 8.2 & 8.0 & 6.5 & 6.3 & 6.2 & 5.9 & 5.9 & 5.9 & 6.7 & 6.8 \\
\hline & & \pm 0.7 & \pm 0.6 & \pm 0.8 & \pm 0.4 & \pm 0.3 & \pm 0.7 & \pm 0.8 & \pm 0.8 & \pm 0.2 & \pm 0.7 & \pm 0.9 & \pm 0.6 \\
\hline & $\mathrm{F}$ & 10.3 & 8.0 & 7.2 & 6.9 & 6.0 & 5.7 & 5.6 & 6.0 & 5.7 & 5.7 & 5.7 & 6.9 \\
\hline & & \pm 0.4 & \pm 0.7 & \pm 0.6 & \pm 0.2 & \pm 0.9 & \pm 0.5 & \pm 0.8 & \pm 0.5 & \pm 0.6 & \pm 0.8 & \pm 0.6 & \pm 0.9 \\
\hline \multirow{4}{*}{$\begin{array}{l}\text { Alkaline } \\
\text { phosphatase } \\
\text { activity } \\
(\mathrm{U} / \ell)\end{array}$} & $\mathrm{M}$ & 541 & 318 & 218 & 133 & 108 & 113 & 102 & 96 & 99 & 89 & 93 & \\
\hline & & \pm 35 & \pm 54 & \pm 29 & \pm 17 & \pm 10 & \pm 12 & \pm 7 & \pm 11 & \pm 14 & \pm 18 & \pm 15 & \pm 16 \\
\hline & $\mathrm{F}$ & 505 & 263 & 186 & 138 & 114 & 118 & 132 & 107 & 97 & 99 & 91 & 107 \\
\hline & & \pm 50 & \pm 16 & \pm 20 & \pm 15 & \pm 19 & \pm 18 & \pm 23 & $\begin{array}{r} \pm 29 \\
\end{array}$ & \pm 12 & \pm 24 & \pm 22 & \pm 11 \\
\hline
\end{tabular}

Each value indicates the mean \pm S.D. for 5 rats.

（3）第 1 腰椎 雄の水分含有量は12力月齢まで減 少した後, 15 力月秢以降增加した。有機成分含有量の 変化はみられなかった。灰分含有量は 6 力月䑪まで増 加した後変化しなかったが，18力月粭以降減少した。 雌の水分含有量は15力月齢まで減少した後, 18 力月跉 以降增加した。有機成分含有量の変化はみられなかっ た。灰分含有量は12力月秢まで増加した後, 減少した。 4. 各骨のカルシウムおよびリン含有量 (Table 4.)

（1）大腿骨 カルシウム含有量は雄では15力月秢 まで増加した後減少した。雌では12力月踖まで増加し た後変化しなかった。リン含有量は雄では 6 力月柃ま で，雌では12力月秢まで増加した後変化しなかった。

（2）脛骨 カルシウム含有量は雄では 6 力月歯ま で増加した後变化しなかったが, 18 月路以降減少し た。雌では 6 力月粭まで増加した後変化しなかった。 リン含有量は雄では 2 力月龄以降 12 力月龄まで変化し なかったが，15力月齢以降減少した。雌では 2 力月秢 以降変化しなかった。

（3）第 1 腰椎 カルシウム含有量は雄では 9 力月 路まで增加した後変化しなかったが, 18 月㱓以降減 少した。雌では18力月齢まで增加した後減少した。リ ン含有量は雄では 3 力月まで増加した後変化しなかっ たが，18力月秢以降減少した。雌では18力月柃まで増 加した後減少した。

5. 血清総カルシウム, リン值およびアルカリフォス ファターゼ活性值 (Table 5.)

血清総カルシウム值は雌雄とも 12 力月秢まで減少し
たが，18カ月橉以降やや高い值であった。血清総りン 值および血清アルカリフォスファターゼ活性值はそれぞ れ雌雄ともに 9 月秢まで減少した後变化しなかった。

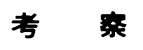

成長に伴う変化をみると, 大腿骨, 脛骨および第 1 腰椎のいずれの重量も雌雄ともに急速な増体重がみら れる1-3力月秢において著しく増加した。この成長 に伴って骨格が形成される時期の骨の含有水分，有機 成分および灰分量の変化はそれぞれ異なり，水分量は 減少，逆に灰分量は増加するが，有機成分量はほとん ど変化しなかった。この結果は，骨の成長に伴って骨 基質が骨の大きさや重さに対応して形成され，この基 質の石灰化が盛んに進んでいることを示していると推 察された。このような変化は 3 力月齢以降もみられ, 骨重量, カルシウムやリン含有量の変化も併せると, ラットの成長に伴う骨成分の变化がなくなり，いわゆ る成熟骨の状態に達するのは雄が 6 力月耣, 雌が 9 力 月秢頃であると推察された。Legros ら $[8]$ は 1 力月齢 と 12 力秢の 2 時点における長骨皮質骨のカルシウム 含有量は有意な差がないことから，成長期におけるカ ルシウム含有量は一定であると報告しているが, 本実 験の結果とは異なっていた。

血清中の総カルシウム值, リン值やアルカリフォス ファターゼ活性值の変化は, 成長に伴って骨形成や骨 芽細胞の活性が減少していることを反映していると考 
えられ，骨重量や含有成分量のそれと一致していた。 成長に伴う変化がわずかになったと考えられる12力 月齢以降では, 骨重量は雌雄とも27あるいは 30 力月齿 で減少するが, 含有成分量の変化はこれよりも早く15 力月粭以降から始まり, 有機成分量は多少の増減がみ られるものの一定の範囲にあるが，水分量は増加，灰 分量は減少することが認められ, この変化は雄の方が 雌よりも明確であった。骨中のカルシウムとリン含有 量は, 雄では大腿骨および脛骨では18あるいは21力月 秢以降にカルシウム含有量の連続的な減少が, 第 1 腰 椎ではカルシウムとリン含有量の減少が18力月㱓以降 に認められる。しかし雌では明確な変化は認められな かった。これらの変化は, 成長期には水分含有量が減 少, 灰分含有が増加した結果と反対の現象であった。 これは，とくに雄の 15 力月粭以降に加秢に伴って骨基 質の状態に変化が起こっていることを示唆していると 考えられた。

Kiebzak ら $[6,7]$ はウィスターラットの $6 ， 12$ およ び24力月秢の 3 時点における大腿骨骨幹の乾燥重量 1 $\mathrm{g}$ 当たりのカルシウム含有量を比べ, 24 力月秢の雄で は12力月秢よりも有意に減少したが, 雌では減少は認 められないことを観察し，本実験の結果と同様に加秢 に伴う变化に雌雄差がみられることを報告している。 一方, Safadi ら[9]は雌のウィスターラットの 7 カ月 秢と 27 カ月秢の 2 時点における第 4,5 腰椎のカルシ ウム含有量は 7 力月齢に比べ 27 力月齢では有意に減少 していることを観祭しており，本実験において差がみ られなかった結果とは相違が認められた。Kiebzak らやSafadi らの報告は，いずれも観察年秢が少な く, カルシウム含有量以外の本実験と共通した成分に ついては詳細に測定していない。

本実験において骨の含有成分量の加齢性変化に雌雄 差があり, 雄において強く認められた結果に関しては 明確な要因は明らかには出来なかった。ただ体重と骨 含有成分量とを比較すると, 雄の体重は 27 月月秢以降 に減少したが, 雌では18力月粭以降増加する傾向を示 したことから，雌では体重の増加が骨の刺激因子とな り, 骨ミネラル量や含有成分の変化を小さくした可能 性が考えられる。その他の要因として, 運動量や性木 ルモンの動態などの差も考えられるが, 本実験に使用 したラットは雌雄ともに同じ大きさのケージ内で飼育 したことから，著しい差はないものと思われる。いず れにしても, 雌雄差の原因に関しては体重, 行動や性 ホルモンの動態, 栄養などの要因が関与していると考
えられたが, 今後の検討課題である。

著者ら [2]は本実験と同一の系統の雌雄ラットの大 腿骨の骨強度と組織学的形態計測法で脛骨近位骨幹端 の secondary spongiosa の梁骨エリアの単位組織中の 骨量 (単位骨量) のピークは12力月秢に認められるこ とを報告しているが, 本実験で測定した重量や含有成 分に比へて時期的な差がみられた。この原因は観察の 対象が骨全体あるいは部分であること, 骨皮質と骨梁 骨で種々の変化に対する感受性が異なること $[5]$, 骨 の種類や同一骨内の部位によって代謝速度が異なるこ と $[10]$ などが考えられる。しかし, 本実験の結果を成 長やそれに続く变化と加㱓に伴う变化を詳細にかつ総 合的に検討すると, 単位骨量のピークすなわち変位点 が12 力月秢にみられた結果と著しい相違はないと判断 された。

\section{要 約}

雌雄 Wistar ラットにおける骨の重量, 含有成分量 および骨関連血清成分の年路变化を雄60匹，雌60匹を 用いて検索した。1，2 および 3 から 30 力月路までは 3 力月間隔の計 12 時点でそれぞれ雄 5 匹, 雌 5 匹を供 し, 大腿骨, 脛骨, 第 1 腰椎の生骨, 乾燥骨および灰 化骨の重量, 水分, 有機成分, 灰分, カルシウムおよ びリン含有量と血清中の総カルシウム值, リン值およ びアルカリフォスファターゼ活性值を測定した。各骨 の重量は, 雌雄とも 3 力月㱓まで急速に, それ以降雌 では12力月齿, 雄では 9 力月秢まで増加した後変化し なかった。しかし雄では27カ月秢以降減少がみられ た。1 カ月秢から 6 あるいは 9 力月齢まで雌雄の各骨 の含有水分量は減少, 灰分量, カルシウムおよびリン 含有量は增加したが, 有機成分量はほとんど変化しな かった。しかし雄では15力月齢以降有機成分量は変化 しなかったが, 水分含有量は増加, 兏分量, カルシウ ムおよびリン量は減少した。血清総カルシウム值は雌

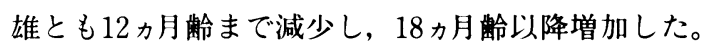
リン值およびアルカリフォスファターゼ活性值は 9 カ月 路まで減少した。本実験で得られた成果は, 既報のラッ トの骨強度や組織形態計測学的に測定した単位骨量のピ 一クが12カ月秢に認められた成果とほぼ一致した。

\section{文献}

[1] Frost, H. M. (1973). In Bone remodeling and its relationship to metabolic bone diseases, Orthopaedic lecture 111. pp28-53, Charles C Thomas, Springfield. 
［2］福田俊・饭田治三(1991). 加餄に伴う雌雄ラットの骨代謝 の変化と卯巣, 精巣摘出年铪による影響の差. 日骨形態 誌, 1, 89-94.

[3] Fukuda, S. and Matsuoka, O. (1979). Maturation process of secondary ossification centers in the rat and assessment of bone age. Exp. Anim . 28, 1-9.

[4] Harrison, J. E., Patt, N., Muller, C., Bayler, T. A., Budden, F. H., Josse, R. G., Murray, T. M., Sturtridge, W. C., Strauss, A., and Goudwin, S. (1991). Bone mineral mass associated with postmenopousal vertebral deformities., Bone Miner., 10, 243-251.

[ 5] Jowsey, J. (1977) . Metabolic diseases of bone. pp 4147, WB Saunders, Philadelphia.

[6] Kiebzak, G. M., Smith, R., Howe, J. C., Gundberg, C. C., and Sacktor, B. (1988). Bone status of senesent male rats: Chemical, morphometric, and biomechanical analyses. J. Bone Miner. Res., 3, 37-45.
[7] Kiebzak, G. M., Smith, R., Gundberg, C. C., Howe, J. C., and Sacktor, B. (1988). Bone status of senesent female rats: Chemical, morphometric, and biomechanical analyses. J. Bone Miner. Res., 3, 439 . 446.

[8] Legros, R., Balnain, N., and Bonel, G. (1987). Age -related changes in mineral of rat and bovine cortical bone. Calcif. Tissue lnt., 41, 137-144.

[9] Safadi, M., Shapira, D., Leichter, 1., Reznick, A., and Silbermann, M. (1988). Ability of different techniques of measuring bone mass to determine vertebral bone loss in aging female rats. Calcif. Tissue lnt ., 42, 375-382.

[10] Wronski, T. J., Smith, J. M., and Jee, W. S. S. (1981). Variations in mineral appositional rate of trabecular bone within the beagle skeleton. Calcif. Tissue lnt . , 33, 583-586. 